\title{
Development and bloom in hybrids of wild passion fruit cultivated in different types of pots and shading levels
}

\author{
Eileen Azevedo Santos ${ }^{1}$, Margarete Magalhães Souza ${ }^{1 *}$, Alexandre Pio Viana ${ }^{2}$, Alex-Alan Furtado de Almeida ${ }^{1}$, loná Santos \\ Araújo $^{3}$, Jôsie Cloviane de Oliveira Freitas ${ }^{1}$
}

1UESC - Depto. de Ciências Biológicas, Rod. Ilhéus-ltabuna,
km 16 - $45662-900$ - Ilhéus, BA - Brasil.
2UENF, Av. Alberto Lamego, 2000 - 28013-600 - Campos
dos Goytacazes, RJ - Brasil.
3UFERSA - Depto. de Ciências Vegetais, Av. Francisco Mota,
572 - 59625-900 - Mossoró, RN - Brasil.
*Corresponding author <souzamagg@yahoo.com.br>

Edited by: Edmilson José Ambrosano

Received May 14, 2010

Accepted December 05, 2011
ABSTRACT: Ornamental hybrids of passion flowers are thoroughly diffused in many countries and used in the decoration of houses and gardens. However, the cultivation of ornamental passion fruits practically unexploited in Brazil. This study aimed at evaluating the growth and blooming of $F_{1}$ hybrids of Passiflora L. (P. sublanceolata J.M. MacDougal [ex P. palmeri var. sublanceolata Killip] vs. $P$. foetida var. foetida L.) cultivated in ceramic and concrete pots under different shading levels. The vegetative and flower evaluations were carried out weekly, in clonal cuttings 60 days after rooting. The height, leaf length and width, the number of internodes and leaves and stem diameter were evaluated using a randomized complete design in a factorial scheme which corresponded to two genotypes, two types of pot, three shading levels ( $25 \%, 50 \%, 75 \%$ ) and seven weeks of evaluation, with four replications. For the variable number of flowers, the same experimental design was adopted. However, the number of evaluations was modified for three periods, but this was not considered for the flower diameter and leaf area. The shading levels of $25 \%$ and $50 \%$ were the most favorable to the growth in height, whereas hybrid genotypes under $25 \%$ shade had greater increase in the number of leaves, internodes and stem diameter, showing tolerance to moderate shade. The higher values for length, width and leaf area were observed at $75 \%$ shade. The greatest number of flowers was verified at $25 \%$ shadow in concrete pots. As for the types of pot, the ceramic ones were more favorable to the growth of hybrid plants during the first weeks of acclimatization to the treatments, and the concrete ones were more propitious to blooming. Thus, the use of hybrid plants in concrete pots for the ornamentation of internal environments is recommended, if they are well illuminated.

Keywords: passion flower, ornamental hybrids, interspecific hybridizations, light intensity, morphological characteristics

\section{Introduction}

The cultivation and commercialization of ornamental plants are activities which have been ongoing for a long time. As ornamental plants, Passiflora L. stands out due to their size, format, exuberance, diversity and the combination of colors of their flowers and leaves. Since the XVII century there has been the ornamental cultivation of these species in Europe, using $P$. caerulea L. and $P$. incarnata L. (Peixoto, 2005). In 1819 the Englishman Thomas Milne succeeded in obtaining the first Passiflora hybrid, through the cross of $P$. racemosa Brot with $P$. caerulea, and, since then, more than 685 interspecific hybrids for ornamental purposes have already been produced and registered /Vanderplank et al., 2003; Ulmer and MacDougal, 2004; King, 2007; Abreu, 2009).

A basic factor for plant development and flower production is the radiation of the sun, which can be characterized by its quality, duration and intensity. The photoperiod acts mainly in the change from the vegetative to the reproductive state, which could be determining for some species in the definition of their blossomtime (Hopkins, 1999). Mattana et al. (2010) observed that chemical composition of the leaf essential oil was influenced by intensities of light in Pothomorphe umbellate (L.) Miquel
The species of the Passiflora genus are widely distributed in tropical and subtropical regions (Vanderplank, 2000; Ulmer and MacDougal, 2004) where the solar radiation is high, but where there are also huge areas of humid and shaded tropical forests. In order to aim at creating a new product for the ornamental plant market, destined for interior decoration, the hypothesis that different shading levels and pots for cultivation interfere in the development of Passiflora hybrids was tested. For this purpose growth and bloom variables were analyzed.

\section{Materials and Methods}

The experiment was conducted at Ilhéus $\left(39^{\circ} 10^{\prime}\right.$ W, $\left.14^{\circ} 39^{\prime} ; \mathrm{S}, 78 \mathrm{~m}\right)$, state of Bahia, Brazil. Two genotypes were evaluated, HD13-133 and HD13-141F hybrids, obtained from the cross of $P$. sublanceolata (Killip) J.M. MacDougal [ex P. palmeri var. sublanceolata Killip] vs. $P$. foetida var. foetida L. at the greenhouse of the Bankof Active Germplasm (BAG-Passifloras).

Hybrids were propagated by cuttings that were removed from the intermediary part of the branches, prepared and standardized with four nodes and four leaves reduced to the half their area. After being selected in bevel, their basal extremities were immersed in talc (inert powder) with synthetic auxin (indole-3 butyric acid - IBA) at a concentration of $2 \mathrm{~g} \mathrm{~kg}^{-1}$. Cuttings were put in 
black $1.5 \mathrm{~L}$ polyethylene bags, containing washed sand. During the rooting period, cuttings were kept in a greenhouse and irrigated twice a day. After rooting, cuttings were transferred to $45 \mathrm{~L}$ ceramic or concrete pots, filled with samples of an Oxisol, previously installed in artificial shading obtained with black plastic type screens. Screens were fixed in wood frames measuring $5 \times 5 \times$ $2 \mathrm{~m}^{3}$ for each light level, under field conditions (www. passifloras.org). Plants were tutored in frames, made of bamboo or wire, nearly $1.0 \mathrm{~m}$ in height. Daily watering, fertilizing every 90 days with 3.9 g urea; 34.29 g monoammonium phosphate (MAP) and $14.97 \mathrm{~g} \mathrm{KCl}$, and micronutrients and urea $\left(23.3 \mathrm{~g} \mathrm{~L}^{-1}\right)$ were applied every 15 days.

The structures propitiated the incidence of $25 \%$, $50 \%$ and $75 \%$ global radiation right under the screen. The data of the photosynthetically active radiation (PAR), temperature and relative humidity, in each environment, measured to the level of the superior extremity of the plants between $8 \mathrm{~h} 00$ and $18 \mathrm{~h} 00$ (Figure 1), were obtained with a visible-light-radiation sensor connected to a Data Logger climatological station. The data corresponding to the climatic variables, global radiation, average temperature, relative air humidity $(\mathrm{RH})$ and precipitation data, of the months corresponding to the experiment and collection of the morphologic data times, were supplied by the UESC Micrometeorological Station located near the experiment installations (Table 1).

Evaluations were carried out between Nov. 2007 and Jan. 2008, in clonal cutting, 60 days after rooting. The following growth variables were evaluated for seven weeks after the hybrid clones had been installed in the experiment: (i) plant height: measuring the length of the stem of the biggest branch, using a tape measure, from the point of connection of the root and stem up to its superior extremity; (ii) length and width of the three biggest leaves; (iii) internodes and leaf number from the same branch used for measurement of the plant height; (iv) stem diameter to the level of the second node of only one branch; (v) leaf area, 109 days after the application of the treatments, using leaf area measurer. For the blossom variable, the number of flowers was registered, daily, for 30 days from the $10^{\text {th }}$ day of blooming, from $8 \mathrm{~h} 00$ to $10 \mathrm{~h} 00$. The flower diameter was obtained in the same period.

A randomized complete design was used in a factorial $(2 \times 2 \times 3 \times 7)$ scheme, corresponding to two genotypes, two types of pots, three shade levels and seven weeks of evaluation, with four replications. The same design was adopted for the number of flowers, three periods (each period corresponding to the average of ten consecutive days of counting). The time factor was not considered for the flower diameter and leaf area; for this reason we used different pots for the measured. Thus were employed four-way analysis of variance
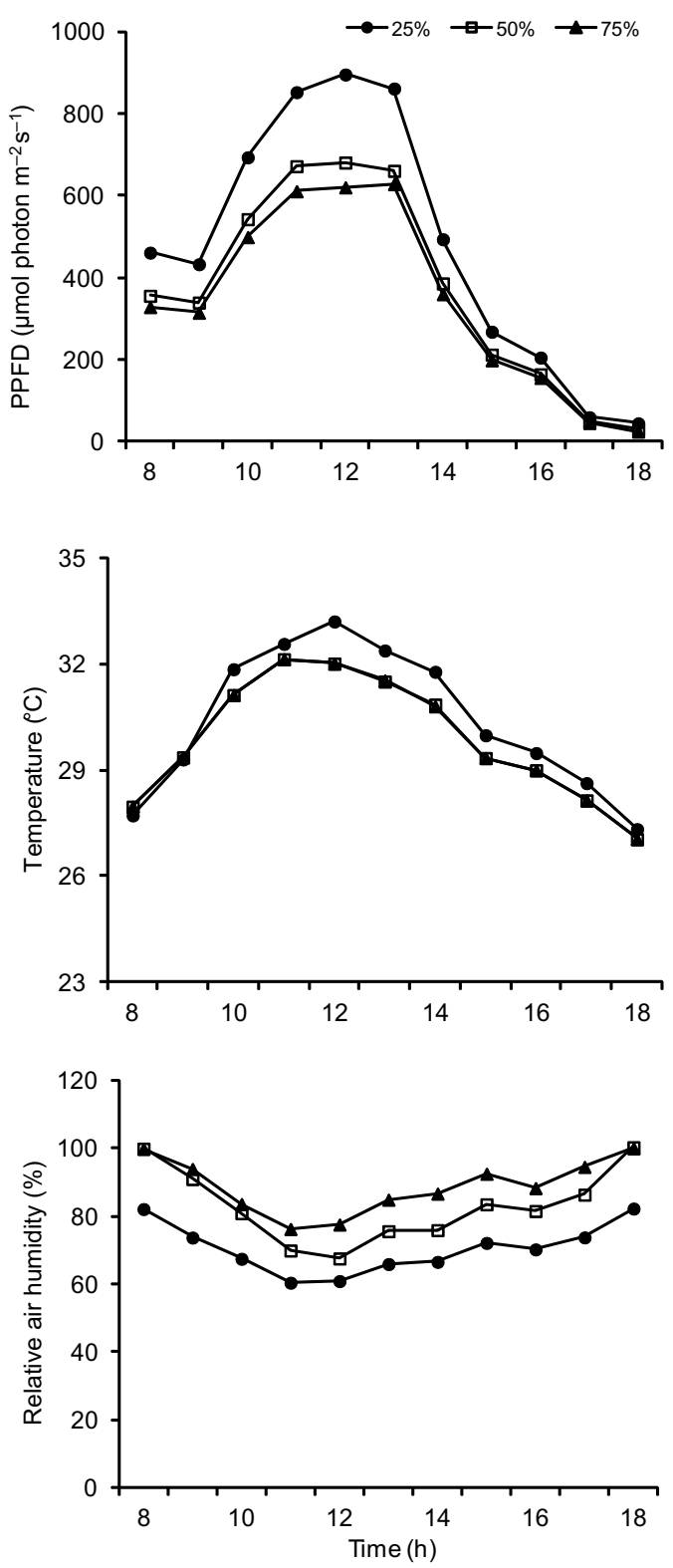

Figure 1 - Day course of the photosynthetically active radiation (PAR), temperature and relative humidity, of each shaded environment, measured at the level of the superior extremity of the plants between $8 \mathrm{~h} 00$ and $18 \mathrm{~h} 00$.

Table 1 - Climatic variables during the experimental period.

\begin{tabular}{lcccc}
\hline Month/year & Global radiation & Average temperature & Relative air humidity & Precipitation \\
\hline & $\mathrm{W} \mathrm{m}^{-2}$ & ${ }^{\circ} \mathrm{C}$ & $\%$ & $\mathrm{~mm}$ \\
Nov. 2007 & 188764.3 & 23.7 & 84.8 & 401.8 \\
Dec. 2007 & 246965.4 & 23.5 & 87.8 & 251.8 \\
Jan. 2008 & 353862.4 & 26.3 & 80.9 & 200.2 \\
\hline
\end{tabular}


model: $(2 \times 2 \times 3 \times 3)$ corresponding to the number of flowers, $(2 \times 2 \times 3)$ corresponding to flower diameter and leaf area and $(2 \times 2 \times 3 \times 7)$ corresponding the other variables. For statistical analysis, the ANOVA, comparison of averages using the Tukey test $(p \leq 0.05)$ and regression analysis between the analyzed variables was performed using the SAS 6 and Genes (Cruz, 2006) software programs.

\section{Results}

There was an effect $(p \leq 0.05)$ for genotypes, types of pots, shading, sampling periods and simple interaction Genotype $\times$ Shading and Genotype $\times$ Type of pots for all characteristics evaluated, except for leaf width and length where did not interaction Genotype $\times$ Type of pots $(p>0.01)$. There was no effect of the pot types for leaf length and width during the evaluation period.

The HD13-133 genotype cultivated in ceramic or concrete pots presented high values in height under 25 $\%$ shading (Figure 2A and Figure $2 \mathrm{~B}$ ) respectively. The hybrid HD13-141 also presented more increase in height when cultivated ceramic pots under $25 \%$ shading (Figure 2D).
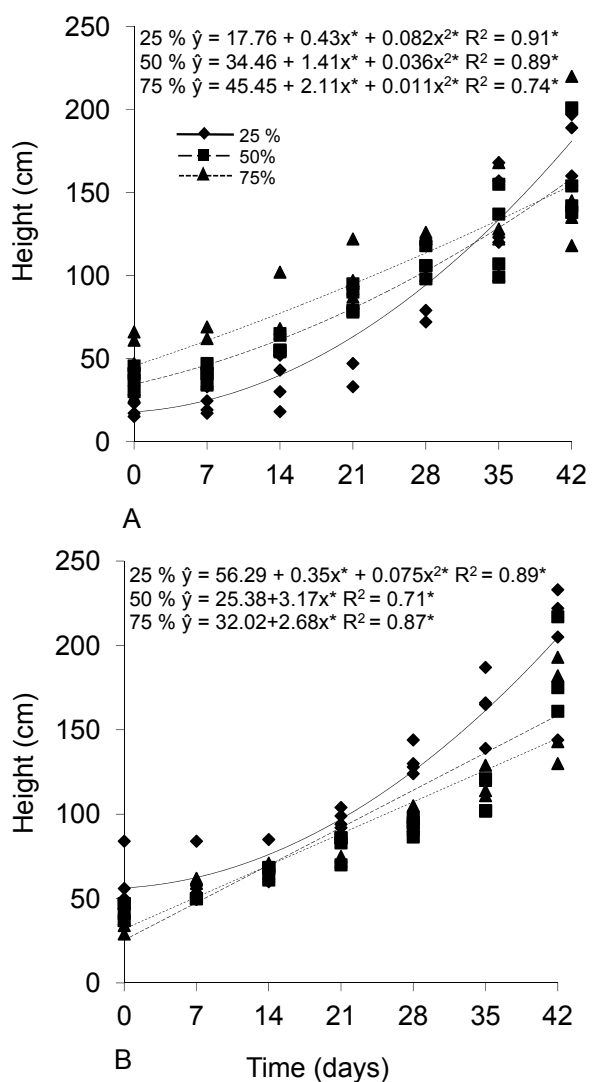

As for the internode number, the two genotypes presented similar performance to that one observed for the plant height variable. The HD13-133 genotype presented great internodes number when cultivated in ceramic or concrete pots under $25 \%$ shading (Figure 3A and $3 \mathrm{~B}$ ) respectively. The HD13-141 genotype presented a higher internode number in ceramic pots under $25 \%$ shading (Figure 3C).

The HD13-133 hybrid presents higher number of leaves $25 \%$ shading, for both types of pots (Figure 4A and 4B). The HD13-141 presented higher response for leaves number when cultivated in ceramic pots under 25 $\%$ shading (Figure $4 \mathrm{C}$ ).

The stem diameter decreased with increasing shading level for the two genotypes. The HD13-133 hybrid had similar values for the shading levels for both types of pots (Figure 5A and B). For the HD13-141 hybrid a greater increase was verified in the stem diameter under $25 \%$ shading when cultivated in concrete pots (Figure 5D).

The most shaded environment promoted greater increases in the leaf length and width for the HD13-133 hybrid genotypes (Figure 6). Therefore, an effect was observed regarding genotypes, types of pots and shading levels, as well as the interaction among them for the
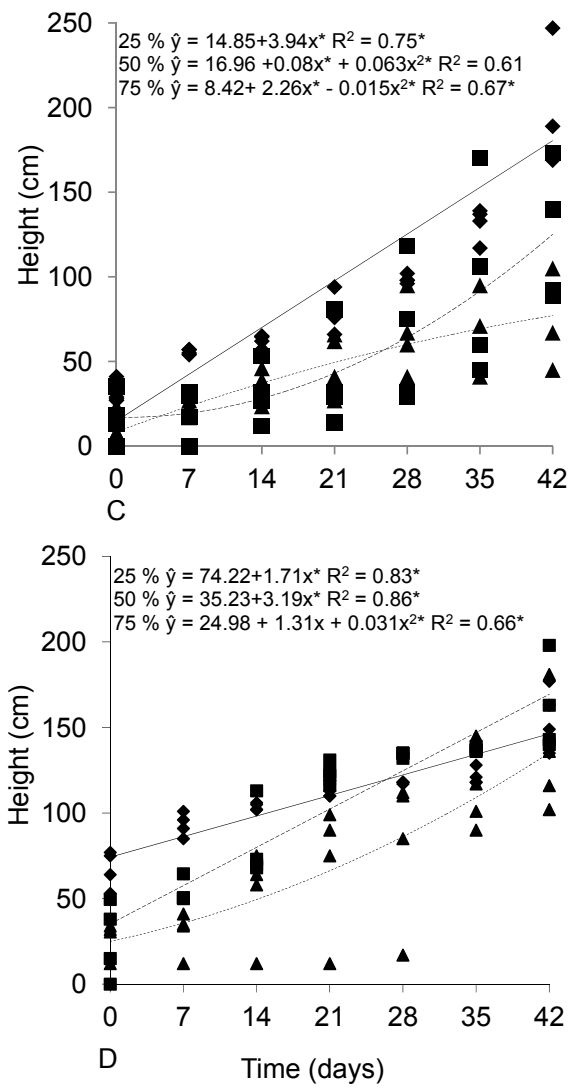

Figure 2 - Growth in height of the longest branch of clonal cuttings of Passiflora L. hybrids, submitted to three shading levels, for 42 days, from 60 days after the rooting of the cuttings from stems. A-B) HD13-133 Hybrids; A) Cultivation in ceramic pots; B) Cultivation in concrete pots. C-D) HD13-141 Hybrids; C) Cultivation in ceramic pots; D) Cultivation in concrete pots. * Significant to $5 \%$ probability by the F test. 

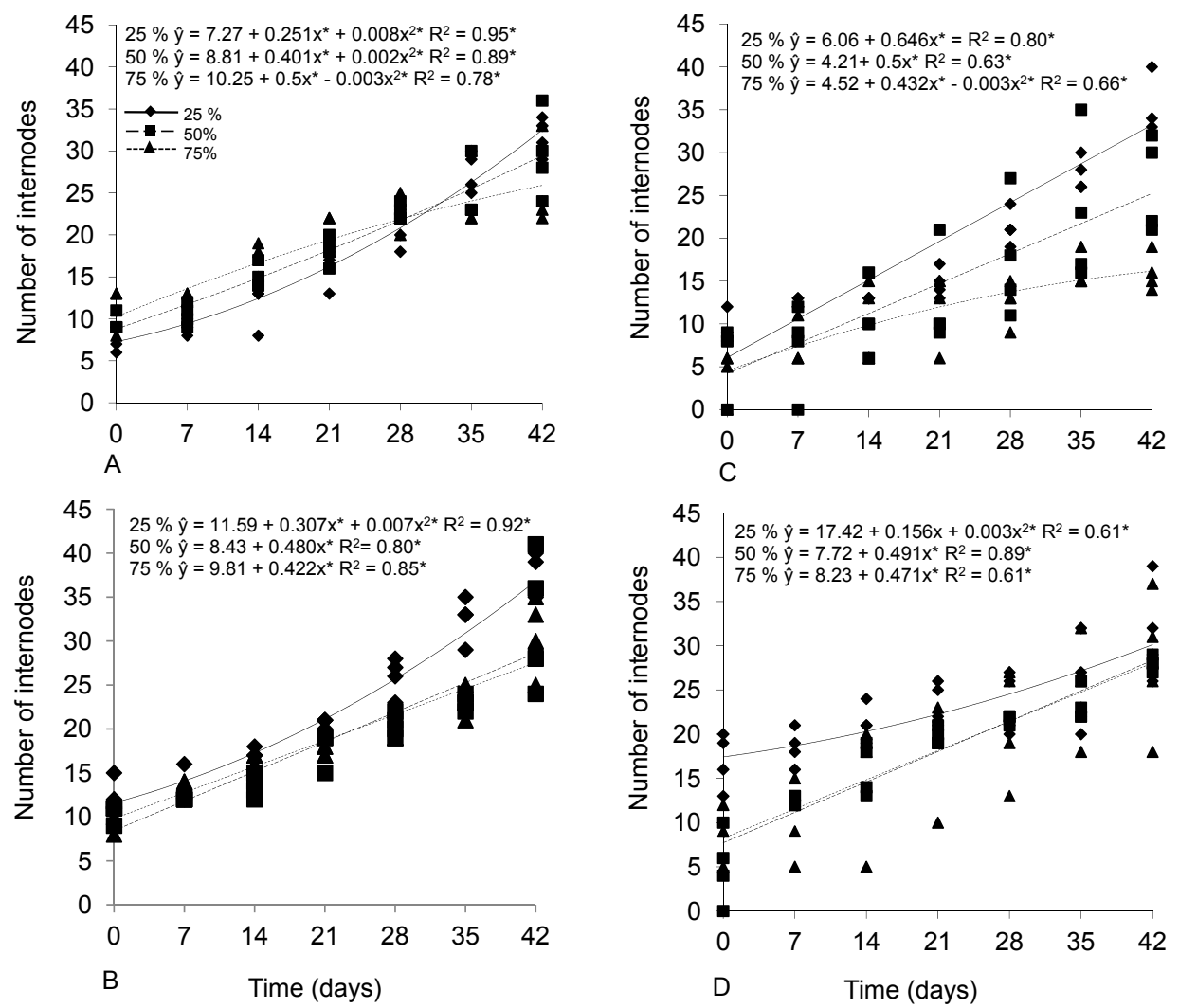

Figure 3 - Number of internodes of the longest branch of clonal cuttings of Passiflora L. hybrids, submitted to three shading levels, for 42 days, from 60 days after the rooting of the cuttings from stem. A-B) HD13-133 Hybrids; A) Cultivation in ceramic pots; B) Cultivation in concrete pots. C-D) HD13-141 Hybrids; C) Cultivation in ceramic pots; D) Cultivation in concrete pots. * Significant to $5 \%$ probability by the F test.

Table 2 - Mean leaf area inHD13-133 and HD13-144 Passiflora L. hybrids submitted to three irradiance levels and cultivated in different types of pots after 109 days of exposure to the treatments.

\begin{tabular}{|c|c|c|c|}
\hline \multirow{2}{*}{ Genotype } & \multirow{2}{*}{ Shading } & Ceramic pot & Concrete pot \\
\hline & & \multicolumn{2}{|c|}{ Leaf area $\left(\mathrm{cm}^{2}\right) \pm$ standard error } \\
\hline & $\%$ & & \\
\hline & 25 & $57.47 \pm 4.08 \mathrm{Ba}$ & $57.66 \pm 0.72 \mathrm{Ab}$ \\
\hline \multirow[t]{3}{*}{ HD13-133 } & 50 & $60.68 \pm 1.61 \mathrm{Ba}$ & $70.99 \pm 4.79 \mathrm{Aab}$ \\
\hline & 75 & $64.26 \pm 2.05 \mathrm{Ba}$ & $77.64 \pm 5.60 \mathrm{Aa}$ \\
\hline & 25 & $44.70 \pm 7.09 \mathrm{Bb}$ & $71.92 \pm 2.08 \mathrm{Ab}$ \\
\hline \multirow[t]{2}{*}{ HD13-141 } & 50 & $70.55 \pm 2.16 \mathrm{Ba}$ & $76.87 \pm 3.02 \mathrm{Aab}$ \\
\hline & 75 & $80.02 \pm 8.26 \mathrm{Ba}$ & $88.33 \pm 5.32 \mathrm{Aa}$ \\
\hline
\end{tabular}

Averages followed by the same letters did not differ (Tukey test, $p \leq-0.05$ ). Capital letters refer to the type of pot effect (within row) and small letters to the shading effect (within column).

leaf area (Table 2). Leaf area increased with increasing shading levels for the two hybrids cultivated in ceramic and concrete pots. The greatest average values for leaf area were found for the two hybrid genotypes cultivated in concrete pots under $75 \%$ of shading (Table 2).

There was no effect of the types of pots and shading levels on the diameter of the flower. Differences were detected only in relation to the genotypes, with the HD13-141 presenting a greater diameter $(64.7 \mathrm{~mm})$ than that of HD13-133 (63.0 mm).
The mean data for number of flowers are shown in Table 3. Effect $(p \leq 0.05)$ of the genotypes, pot types, shading and sampling periods, as well as the interaction of these factors, was verified. Flower number was higher when shading levels were decreased during the evaluation period, for the two hybrid genotypes cultivated in the different types of pots. The greatest average values were observed for the hybrid HD13-133 cultivated in concrete pots under $25 \%$ shading, in the last week of evaluation (Table 3). 


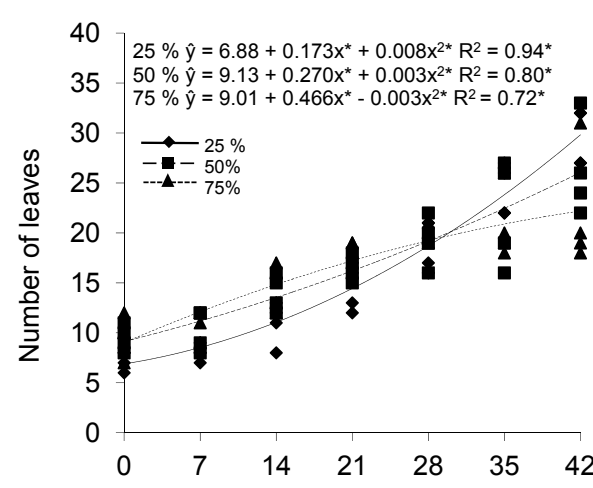

A

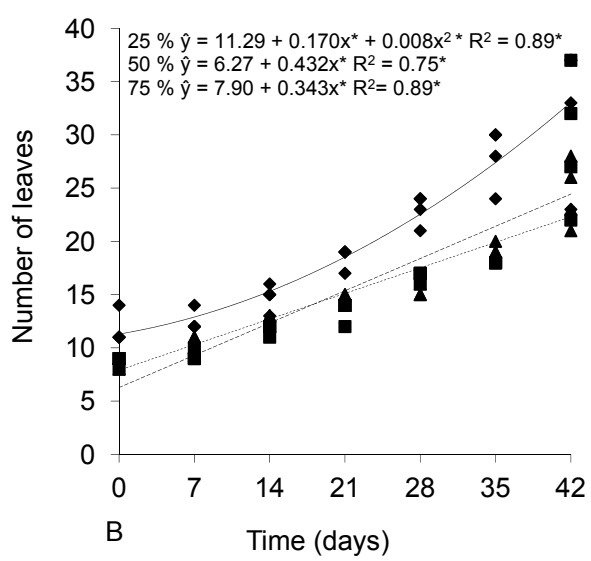

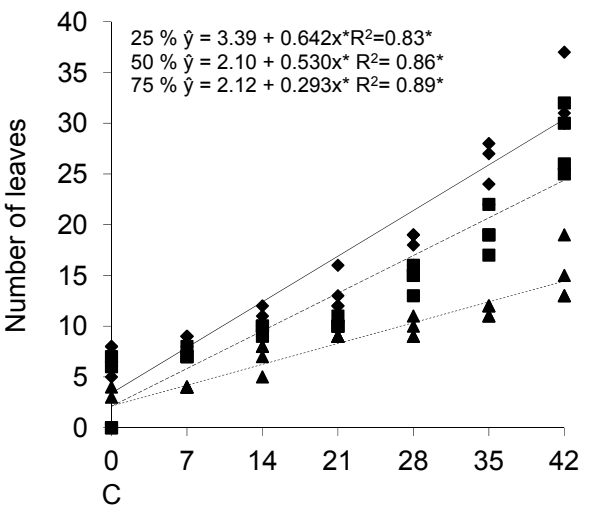

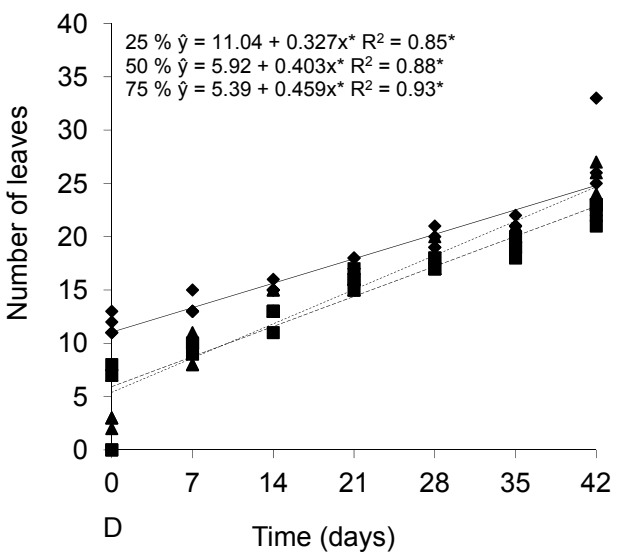

Figure 4 - Number of leaves of the longest branch of clonal cuttings of Passiflora L. hybrids, submitted to three shading levels, for 42 days, from 60 days after the rooting of the cuttings from stem. A-B) HD13-133 Hybrids; A) Cultivation in ceramic pots; B) Cultivation in concrete pots. C-D) HD13-141 Hybrids; C) Cultivation in ceramic pots; D) Cultivation in concrete pots. * Significant to $5 \%$ probability by the F test.

Table 3 - Mean number of flowers in Passiflora L. hybrid genotypes submitted to three shading levels cultivated in ceramic and concrete pots 30 days after exposure to the treatments.

\begin{tabular}{|c|c|c|c|c|c|c|c|}
\hline \multirow{3}{*}{ Genotype } & \multirow{3}{*}{ Shading } & \multicolumn{3}{|c|}{ Ceramic pot } & \multicolumn{3}{|c|}{ Concrete pot } \\
\hline & & \multicolumn{6}{|c|}{ Time (days) \pm standard error } \\
\hline & & 10 & 20 & 30 & 10 & 20 & 30 \\
\hline & $\%$ & & & & & & \\
\hline \multirow[b]{2}{*}{ HD13-133 } & $\begin{array}{l}25 \\
50\end{array}$ & $\begin{array}{l}2.42 \pm 0.43 \mathrm{Ab} \\
1.13 \pm 0.10 \mathrm{Bb}\end{array}$ & $\begin{array}{l}3.14 \pm 0.40 \mathrm{Aab} \\
2.13 \pm 0.17 \mathrm{Bab}\end{array}$ & $\begin{array}{l}3.79 \pm 0.60 \mathrm{Aa} \\
3.06 \pm 0.13 \mathrm{Aa}\end{array}$ & $\begin{array}{l}2.94 \pm 0.53 \mathrm{Ac} \\
1.39 \pm 0.49 \mathrm{Bb}\end{array}$ & $\begin{array}{l}3.97 \pm 0.29 \mathrm{Ab} \\
3.20 \pm 0.19 \mathrm{Aa}\end{array}$ & $\begin{array}{l}7.50 \pm 0.21 \mathrm{Aa} \\
3.03 \pm 0.43 \mathrm{Ba}\end{array}$ \\
\hline & 75 & $0.64 \pm 0.26 \mathrm{Bb}$ & $1.76 \pm 0.21 \mathrm{Ba}$ & $2.08 \pm 0.08 \mathrm{Ba}$ & $0.26 \pm 0.19 \mathrm{Cb}$ & $1.63 \pm 0.23 \mathrm{Ba}$ & $2.19 \pm 0.12 \mathrm{Ba}$ \\
\hline \multirow[b]{2}{*}{ HD13-141 } & $\begin{array}{l}25 \\
50\end{array}$ & $\begin{array}{l}1.18 \pm 0.32 \mathrm{Ab} \\
1.01 \pm 0.48 \mathrm{Ab}\end{array}$ & $\begin{array}{l}2.98 \pm 0.17 \mathrm{Aa} \\
2.74 \pm 0.06 \mathrm{Aa}\end{array}$ & $\begin{array}{l}2.84 \pm 0.34 \mathrm{Aa} \\
2.75 \pm 0.21 \mathrm{Aa}\end{array}$ & $\begin{array}{l}2.19 \pm 0.48 \mathrm{Ab} \\
0.90 \pm 0.09 \mathrm{Bb}\end{array}$ & $\begin{array}{l}3.97 \pm 0.36 \mathrm{Aa} \\
3.01 \pm 0.21 \mathrm{Aa}\end{array}$ & $\begin{array}{l}2.91 \pm 0.28 \mathrm{Ab} \\
2.85 \pm 0.10 \mathrm{Aa}\end{array}$ \\
\hline & 75 & $0.08 \pm 0.08 \mathrm{Bb}$ & $1.03 \pm 0.13 \mathrm{Ba}$ & $1.33 \pm 0.17 \mathrm{Ba}$ & $0.04 \pm 0.04 \mathrm{Ba}$ & $0.71 \pm 0.07 \mathrm{Ba}$ & $0.64 \pm 0.19 \mathrm{Ba}$ \\
\hline
\end{tabular}

Averages followed for the same letters did not differ (Tukey test, $p \leq 0.05$ ). Capital letters refer to the shading effect (within row) and small letters to the time effect (within column).

\section{Discussion}

The irradiance of the environment in which the plants grow is of fundamental importance, because the adaptation of the plants to this environment depends on the adjustment of their photosynthetic apparatus, so that the light is used in a possibly more efficient way (Lima Júnior et al., 2006). High irradiance may reduce the productivity of tropical plants, as in Min- quartia guianensis Aubl. (Dias and Marenco, 2007). Then, it is interesting to know how hybrids genotypes of Passiflora respond at shading environment and cultivated in types of pots that are the more common in the market. The responses of the plants can be observed in the growth variables, as height of plant, stem diameter and leave number, and are used for making inferences about the tolerance to shading levels (Almeida et al., 2005). 

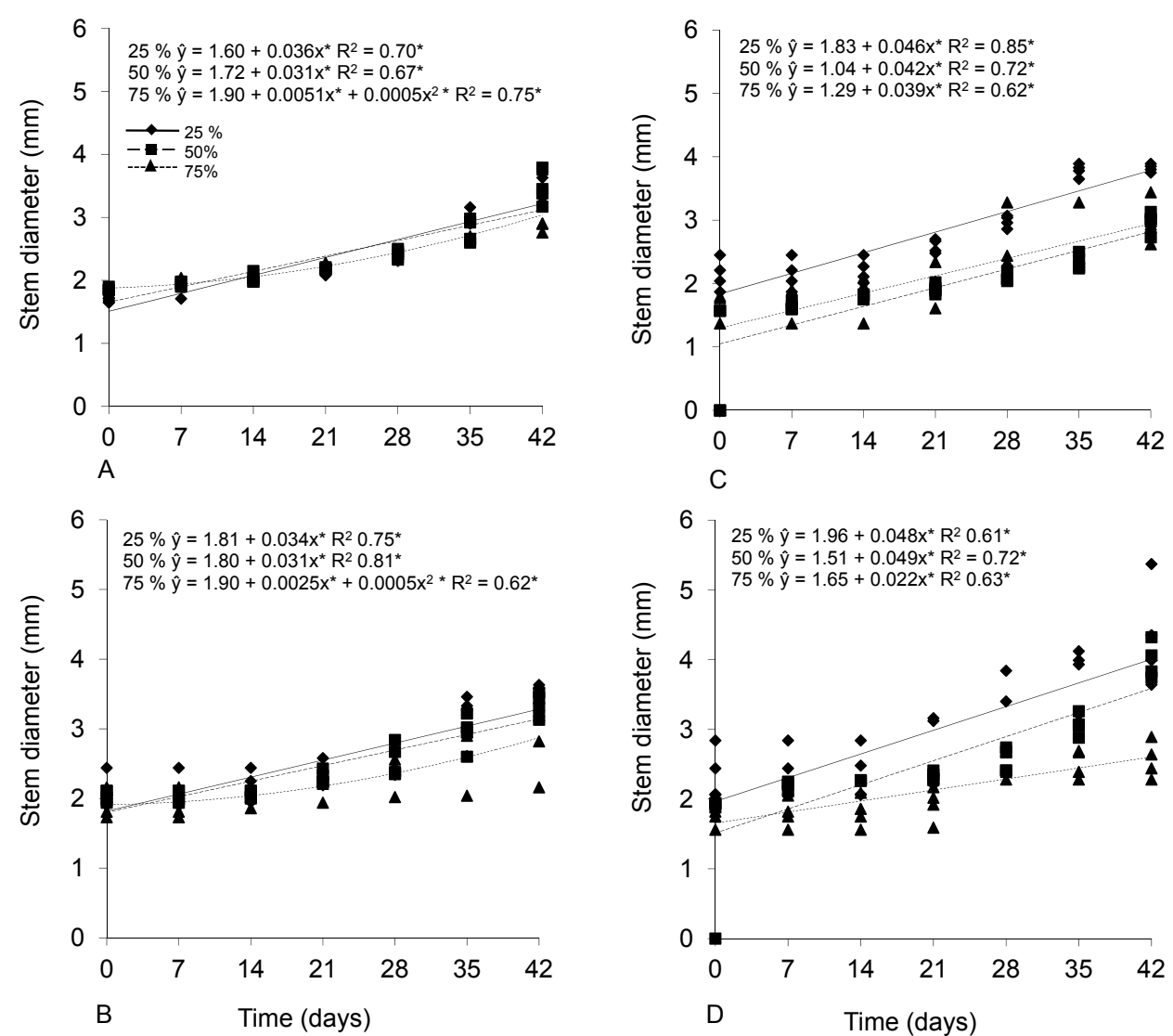

Figure 5 - Stem diameter to the level of the second node of clonal cuttings of Passiflora L. hybrids, submitted to three shading levels, for 42 days, from 60 days after the rooting of the cuttings from stem. A-B) HD13-133 Hybrids; A) Cultivation in ceramic pots; B) Cultivation in concrete pots. C-D) HD13-141 Hybrids; C) Cultivation in ceramic pots; D) Cultivation in concrete pots. ${ }^{*}$ Significant to $5 \%$ probability by the F test.

Generally, the condition of $75 \%$ shading was unfavorable to the growth of the plants, while the greatest irradiances, obtained with 25 and $50 \%$ shading, favored the development of the hybrid genotypes of Passiflora, promoting greater growth in height in moderate shade. Taking into account the effect of the interactions Genotype $\times$ Type of pot and Genotype $\times$ Shading, the genotypes presented different responses to each shading level and type of pot for almost all evaluated characteristics, and HD13-133 was superior in relation to plant height, internode number and number of flowers when cultivated in ceramic pot under $25 \%$ shading.

The responses of the hybrid genotypes, in relation to the plant height, varied according to the shading level. The height is a good characteristic to evaluate the response of the plant to the light, because the species have different response patterns, related to their capacity to adapt to the variations in the light intensity (Zanella et al., 2006). Although in this study greater heights had occurred in more illuminated environments, passion fruit plants under different shading levels presented greater growths in height in environments with $80 \%$ shading (Zanella et al., 2006). Similarly, in the ornamental pineapple Tapeinochilos ananassae (Hassk.) K. Schum. the lowest luminosity was obtained with $82 \%$ shading, promoted higher stem height (Meleiro and Graziano, 2007).

Low tolerance to high shading levels was furthermore evidenced in this study by the smallest development of the plants under low irradiance conditions (Felfili et al., 1999). Thus, the reduced growth observed for the most shaded environment suggested that condition is limiting for their development. In the present study, the hybrid presented greater height under lower levels of shading and they also presented greater internode numbers under the same conditions. The internodes numbers reflect the growth of the plants in height, and the ratio (plant height/number of internodes) characterizes the average length of the internodes (Lécolier et al., 2009). In field studies with three species of Passiflora, 147 days after sowing, a higher number of internodes was verified in relation to the main branch for $P$. gibertii N.E. Brown when compared to P. edulis f. flavicarpa O. Deg. and P. cincinnata Mast. (Silva et al., 2006).

In Passiflora hybrids, the increase of the number of leaves was proportional to the increase in the irradiance. Similar to this, a lower number of leaves for seedlings was verified in $P$. edulis Sims, cultivated under 70 $\%$ shade (Silva et al., 2006). In Sclerolobium paniculatum seedlings cultivated in full sun and $50 \%$ shading result- 

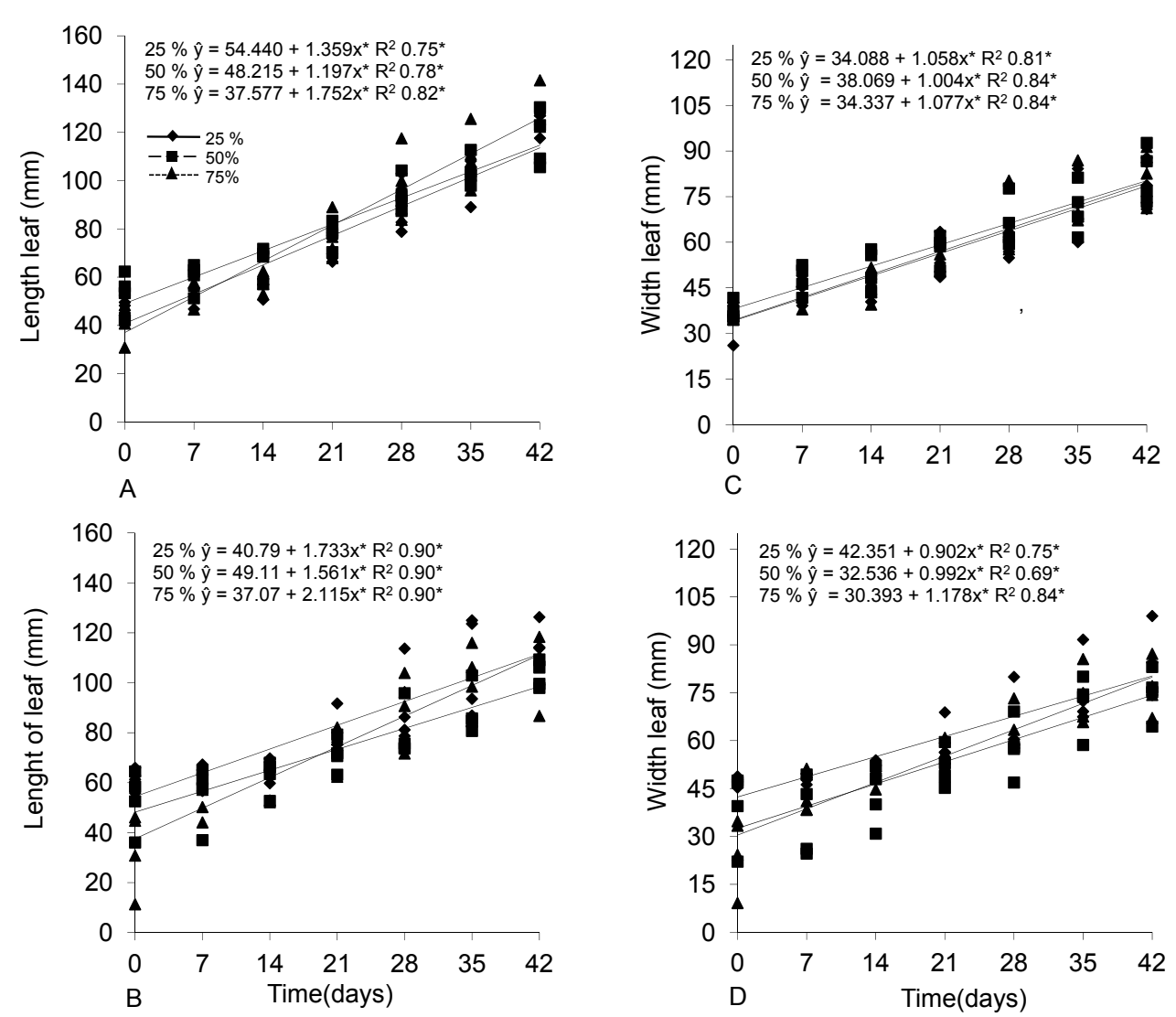

Figure 6 - Length and width of the three longest leaves of clonal cuttings of Passiflora L. hybrids, submitted to three shading levels, for 42 days, from 60 days after the rooting of the cuttings from stem. A, C) HD13-133 Hybrids; B, D) HD13-141 Hybrids. * Significant to $5 \%$ probability by the $\mathrm{F}$ test.

ed in a higher number of leaves (Felfili et al., 1999). The genotype can also be an important factor in determining the number of leaves in plants. Under field conditions, $P$. gibertii presented higher numbers of leaves in relation to $P$. cincinnata and $P$. edulis $\mathrm{f}$. flavicarpa under the same conditions (Vasconcelos et al., 2005).

In this study a higher increase for the stem diameter in conditions of higher light (25\% shading) intensity was shown. Similar results obtained in the arboreal species Pseudopiptadenia psilostachya, with higher values for the stem diameter at levels of 30 and $50 \%$ shading (Fonseca et al., 2006). The growth in diameter depends on the exchange activity which, in turn, is stimulated by carbohydrates produced by the photosynthesis and hormones translocated from the apical areas (Paiva et al., 2003). Although higher values have been verified for the stem diameter under $25 \%$ shading, the difference between this and the other shading levels was of little significance.

The leaf area is a characteristic which allows one to analyze the shade tolerance of different species, since it is directly correlated with the photosynthesizing surface area (Lima Júnior et al., 2006). In the present study, the elevation of the shading resulted in the greater leaf area. Similar to the results found in this study, passion fruit seedlings presented higher values for leaf area when submitted to the highest shading levels (Silva et al., 2006). There is the need to enlarge the photosynthesizing surface to maximize the light absorption, searching for a better use of the low irradiance intensities (Almeida et al., 2005). However, there was reduction in the leaf area in passion fruit under low light intensity conditions (Kluge, 1998). The determination of the leaf area is important in the establishment of physiologic processes related to growth and development, including transpiration intensity, liquid assimilatory rates, leaf area index (Franco and Dillenburgl, 2007).

Leaf length and width presented higher growth in low irradiance conditions, under $75 \%$ shade. Expansion of the leaf under low luminosity is frequently reported in other species, and indicates the way the plant compensates for the decrease in light, taking better advantage of this resource with the increase in surface (Franco and Dillenburgl, 2007).

The $25 \%$ shade conditions favored not only the growth but also the bloom of the hybrid genotypes, and a greater number of flowers occurred in conditions of higher irradiance which decreased gradually with the increase in the shading. The decrease in the number of flowers due to intense shading can be related to the 
reduction of the photosynthesis rate (Cavichioli et al., 2006). These results reinforced the studies that showed lower production on the part of the passion fruit plant with the decrease in the levels of solar radiation, and flowers were not observed under intense shading (Menzel and Simpson, 1988). In Dimocarpus longan Lour., floral induction has been done with potassium chlorate (Potchanasin et al., 2009; Sringarm et al., 2009a) but shade prevented floral induction in this species despite the treatment (Sringarm et al., 2009b).

Yellow passion flower presented greater numbers of flowers in environments without shade and with artificial light (Cavichioli et al., 2006). Among the climatic factors, the photoperiod performs an important function in the yellow passion fruit blossom, since this species only bloom when submitted to 12 or more hours of light (Watson and Bowers, 1965). In the hybrid genotypes, the beginning of the blossom occurred first in the less shaded environment, demonstrating the importance of light in that process, because increases in irradiance are one of the factors that can induce blooming (Soares et al., 2009).

Although the difference among the types of pots used was small, cultivation in ceramic pots proved to be more favorable to the growth of the hybrids. This can be attributed to the claylike constitution of the ceramic, which possesses a high capacity of water adsorption, making nutrients more available to the plants, an essential condition for growth. Studies developed in the passion fruit, under protected conditions, showed that hydric stress affects plant growth appreciably (Menzel et al., 1986). Soil moisture should be adapted for each situation of cultivation. For the passion fruit, maintaining the soil close to the field capacity, principally in the blooming period (Menzel et al., 1986). According to the authors, the water content of the passion fruit should correspond to matrix potential values close to $-0.06 \mathrm{MPa}$, for sandy soils, and superior to $-0.02 \mathrm{MPa}$, for soils from medium to claylike texture. It was determined that the water potential of the soil for the passion fruit plant should not be inferior to $-0.02 \mathrm{MPa}$ during the flower differentiation period (Souza et al., 2006).

\section{Acknowledgements}

The authors thank CAPES /Coordenação de Aperfeiçoamento de Pessoal de Nivel Superior) for the scholarship; FAPESB (Fundação de Amparo à Pesquisa do Estado da Bahia), CNPq (Conselho Nacional de Desenvolvimento Científico e Tecnológico) and UESC (Universidade Estadual de Santa Cruz) for financial support.

\section{References}

Abreu, P.P.; Souza, M.M.; Santos, E.A.; Pires, M.V.; Pires, M.M.; Almeida, A.-A.F. 2009. Passion flower hybrids and their use in the ornamental plant market: perspectives for sustainable development with emphasis on Brazil. Euphytica 166: 307-315.
Almeida, S.M.Z.; Soares, A.M.; Castro, E.M.; Vieira, C.V.; Gajego, E.B. 2005. Morphologic alterations and biomass allocation in young plants of forestry species under different conditions of shading. Ciência Rural 35: 62-68 (in Portuguese, with abstract in English).

Cavichioli, J.C.; Ruggiero, C.; Volpe, C.A.; Paulo, E.M.; Fagundes, J.L.; Kasai, F.S. 2006. Flowering and fructification of yellow passion fruit submitted to artificial light, irrigation and shade. Revista Brasileira de Fruticultura 28: 92-96 (in Portuguese, with abstract in English).

Cruz, C.D. 2006. Program GENES: Experimental Statistics and Matrices. UFV, Viçosa, MG, Brazil (in Portuguese).

Dias, D.P.; Marenco, R.A. 2007. Fluorescence characteristics and photoinhibition in saplings of manwood on clear days and under overcast conditions. Scientia Agricola 64: 595-600.

Felfili, J.M.; Hilgbert, L.F.; Franco, A.C.; Silva-Souza, J.C.; Resende, A.V.; Nogueira, M.V.P. 1999. Behaviour of Sclerolobium paniculatum Vog. var. rubiginosum (Tul.) Benth. seedlings under different simulated shade intensities. Revista Brasileira de Botânica 22: 297-301 (in Portuguese, with abstract in English).

Fonseca, M.G.; Leão, N.V.M.; Santos, F.A.M. 2006. Seed germination and initial growth of Pseudopiptadenia psilostachya (DC.) G.P. Lewis \& M.P. Lima (Leguminosae) seedlings under different shade levels. Revista Árvore 30: 885-891 (in Portuguese, with abstract in English).

Franco, A.M.S.; Dillenburgl, L.R. 2007. Morphological and physiological adjustments in young plants of Araucaria angustifolia (Bertol.) Kuntze in response to shading. Hoehnea 2: 135-144 (in Portuguese, with abstract in English).

Hopkins, W.G. 1999. Introduction to Plant Physiology. John Wiley, New York, NY, USA.

King, L.A. 2007. Newly-Registered Cultivars. Passiflora 17: 1-37.

Kluge, R.A. 1998. Passion fruit (Passiflora sp.). p. 32-47. In: Castro, P.R.C.; Kluge, R.A., eds. Tropical fruit ecophysiology. Nobel, São Paulo, SP, Brazil (in Portuguese).

Lécolier, A.; Verdeil, J.-L.; Escoute, J.; Chrestin, H.; Noirot, M. 2009. Laurina mutation affected Coffea arabica tree size and shape mainly through internode dwarfism. Trees 23: 10431051.

Lima Júnior, E.C.; Alvarenga, A.A.; Castro, E.M.; Vieira, V.C.; Barbosa, J.P.R.A.D. 2006. Physioanatomy traits of leaves in young plants of Cupaniavernalis Camb. subjected to different shading levels. Revista Árvore 30: 33-41 (in Portuguese, with abstract in English).

Mattana, R.S.; Vieira, M.A.R.; Marchese, J.A.; Ming, L.C.; Marques, M.O.M. 2010. Shade level effects on yield and chemical composition of the leaf essential oil of Pothomorphe umbellate (L.) Miquel. Scientia Agricola 67: 414-418.

Meleiro, M.; Graziano, T.T. 2007. Development of Tapeinóquilo under different luminosity conditions. Revista Brasileira de Horticultura Ornamental 13: 63-72 (in Portuguese, with abstract in English).

Menzel, C.M.; Simpson, D.R.; Dowling, A.J. 1986. Water relations in passion fruit: effect of moisture stress on growth, flowering and nutrient uptake. Scientia Horticulturae 29: 239-349.

Menzel, C.M.; Simpson, D.R. 1988. Effect of continous shading on growth, flowering and nutrient uptake of passion fruit. Scientia Horticulturae 35: 77-88. 
Paiva, C.L.; Guimarães, R.J.; Souza, C.A.S. 2003. Influence of different shading levels on the growth of coffee seedlings (Coffea arabica L.). Ciência e Agrotecnologia 27: 134-140 (in Portuguese, with abstract in English).

Peixoto, M. 2005. Problems and perspectives of the ornamental passion fruit. p. 457-464. In: Faleiro, F.G.; Junqueira, N.T.V.; Braga, M.F., eds. Passion fruit: germplasm and genetic breeding. Embrapa Cerrados, Planaltina, DF, Brazil (in Portuguese).

Potchanasin, P.; Sringarm, K.; Sruamsiri, P.; Bangerth, K.F. 2009. Floral induction (FI) in longan (Dimocarpus longan Lour.) trees: Part I. Low temperature and potassium chlorate effects on FI and hormonal changes exerted in terminal buds and sub-apical tissue. Scientia Horticulturae 122: 288-294.

Silva, M.L.S.; Viana, A.E.S.; São José, A.R.; Amaral, C.L.F.; Matsumoto, S.N.; Pelacani, C.R. 2006. Passion fruit (Passiflora edulis Sims f. flavicarpa Deg.) seedling development under different shading levels. Acta Scientiarum Agronomy 28: 513521

Soares, A.B.; Sartor, L.R.; Adami, P.F.; Varella, A.C.; Fonseca, L.; Mezzalira, J.C. 2009. Influence of luminosity on the behavior of eleven perennial Summer forage species. Revista Brasileira de Zootecnia 38: 443-451 (in Portuguese, with abstract in English).

Souza, V.F.; Folegatti, M.V.; Frizzone, J.; Corrêa, R.A.L; Viana, T.V.A. 2006. Soil moisture in the root zone of passion fruit tilled under drip irrigation. Engenharia Agricola 26: 365-373 (in Portuguese, with abstract in English).

Sringarm, K.; Potchanasin, P.; Sruamsiri, P.; Bangerth, K.F. 2009a. Floral induction (FI) in longan (Dimocarpus longan Lour.) trees: the possible participation of endogenous hormones II. Low temperature and potassium chlorate effects on hormone concentrations in and their export out of leaves. Scientia Horticulturae 122: 295-300.
Sringarm, K.; Potchanasin, P.; Naphrom, D.; Bangerth, K.F. 2009b. Floral induction (FI) in longan (Dimocarpus longan Lour.) trees. III: Effect of shading the trees on potassium chlorate induced FI and resulting hormonal changes in leaves and shoots. Scientia Horticulturae 122: 301-311.

Ulmer, T.; MacDougal, J. 2004. Passiflora: Passionflowers of the world. Timber Press, Portland, OR, USA.

Watson, D.P.; Bowers, F.A.I. 1965. Long days produce flowers on passion fruit. Hawaii Farm Science 14: 3-5.

Vanderplank, J. 2000. Passion Flowers. MIT Press, Cambridge, UK.

Vanderplank, J.; Blanco, E.G.; Feuillet, C.; Frank, A.; King, L.; Kugler, E.; Laurens, C.; MacDougal, J.; Skimina, T. 2003. The International Passiflora Register 2003. Passiflora Society International 1: 1-36.

Vasconcelos, M.A.S.; Silva, A.C.; Reis, A.C. 2005. Passion fruit ecophysiology and its implications on diversified exploitation. p. 259-313. In: Faleiro, F.G.; Junqueira, N.T.V.; Braga, M.F., eds. Passion Fruit: germplasmand genetic breeding. Embrapa Cerrados, Planaltina, DF, Brazil (in Portuguese).

Zanella, F.; Soncela, R.; Lima, A.L.S. 2006. Formation of yellow passion fruit seedlings under different shading treatments in Ji-Paraná/RO. Ciência e Agrotecnologia 30: 880-884 (in Portuguese, with abstract in English). 